\title{
KINETIC STUDY OF SULFUR DIOXIDE ABSORPTION INTO DOLOMITE-BRUCITE SUSPENSIONS
}

\author{
SIMION DRAGAN ${ }^{\mathrm{a}}$, ADINA GHIRISAN (MICLAUS) ${ }^{\mathrm{a}^{*}}$
}

\begin{abstract}
The influence of the dolomite-brucite concentration and temperature on the global process of sulfur dioxide, $\mathrm{SO}_{2}$, absorption into dolomite-brucite suspensions was established. According to the proposed macro-kinetic model, the chemical reaction between $\mathrm{H}_{2} \mathrm{SO}_{3}$ and $\mathrm{MeCO}_{3}$ takes place into the adsorbed layer, at the outer surface of the granules. The low values of the activation energies obtained, Ea $<<25.1 \mathrm{~kJ} / \mathrm{mol}$, confirmed for working conditions, that the global chemisorption process was limited to diffusion stage. At suspension concentrations lower than $5 \%$ and high temperatures, the chemisorption was carried out according to the shrinking core model without crust, when the diffusion of $\mathrm{H}_{2} \mathrm{SO}_{3}$ through the liquid phase is the limitative stage. At concentrations higher than $10 \%$ the chemisorption was carried out according to the unreacted core model with crust formation, when the diffusion of $\mathrm{H}_{2} \mathrm{SO}_{3}$ through the crust of products remains the limitative phenomenon.
\end{abstract}

Keywords: dolomite-brucite suspension, sulfur dioxide, chemisorption, activation energy, macro-kinetic mechanism.

\section{INTRODUCTION}

Industrial development has caused emissions of gas pollutants $\mathrm{SO}_{2}$, $\mathrm{SO}_{3}, \mathrm{NO}_{\mathrm{x}}, \mathrm{HCl}, \mathrm{HF}$, etc.) which were released into the atmosphere, thus affecting seriously the quality of the environment. An important case with a major environmental impact is the emission of sulfur dioxide [1-10].

Annual sulfur dioxide emissions have been estimated to be approximately 160 million tons, half being produced by industrial activities [11]. The industrial sectors that contribute to the $\mathrm{SO}_{2}$ emissions are the metallurgical ore refining and power industry that uses fossil fuels as raw material. Therefore the desulphurization of gaseous emissions from burning fossil fuels is very important.

\footnotetext{
a Babeş-Bolyai University, Faculty of Chemistry and Chemical Engineering, 11 Arany Janos str., RO-400028, Cluj-Napoca, Romania

*Corresponding author: ghirisan@chem.ubbcluj.ro
} 
In the last 30-40 years, a significant number of gas scavenging technologies have developed, amid the consumption of fossil fuels and the continued increase in energy demand [12]. Desulphurization technologies are classified in three main categories: dry, semi-dry and wet $[13,14]$. The wet desulfurization process achieves one of the highest purification efficiency and reliability, being the most commonly used technology for controlling the emission of $\mathrm{SO}_{2}$ in the world [3,15-18].

Retention of $\mathrm{SO}_{2}$ in suspension of calcium carbonate (rock or precipitated) is the most used wet process, due to the low cost $[1,4,8,9,19,20]$. Desulphurization by this method leads to large amounts of gypsum, which is a storage problem. Nowadays, the research in the desulphurization of flue gas is oriented to develop technologies that lead to compounds which can be completely reused. The wet flue gas desulfurization using dolomite-brucite suspension is of great perspective, reducing at half the amount of the gypsum, and recovering a part of sulfur dioxide as $\mathrm{MgSO}_{4}$, with many practical uses.

The present study investigates the macro-kinetic mechanism of the $\mathrm{SO}_{2}$ absorption into dolomite-brucite $\left(\mathrm{CaMg}\left(\mathrm{CO}_{3}\right)_{2} \mathrm{Mg}(\mathrm{OH})_{2}\right)$ suspensions. It was determined experimentally the influence of the temperature and the dolomite-brucite concentration on the global process.

\section{RESULTS AND DISCUSSION}

The influence of dolomite-brucite concentration on the $\mathrm{SO}_{2}$ absorption rate at a temperature range from 293 to $333 \mathrm{~K}$ and stirring speed of $200 \mathrm{rpm}$, was observed. An example, for a temperature of $293 \mathrm{~K}$, is shown in Figure 1.

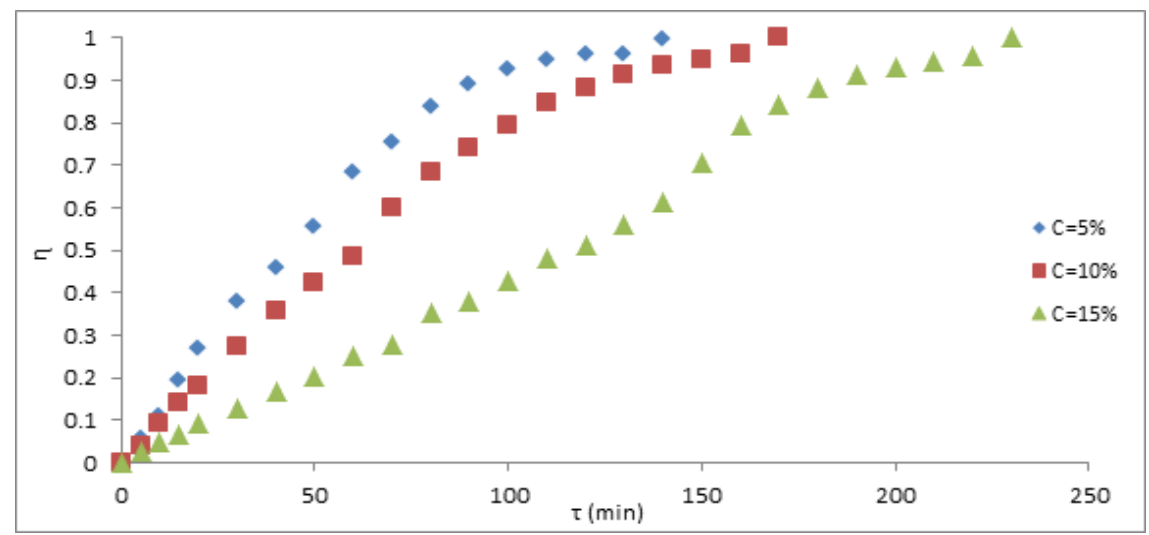

Figure 1. Influence of the suspension concentration on $\mathrm{SO}_{2}$ absorption rate, $\mathrm{T}=293 \mathrm{~K}$ 
The results indicate that the absorption of $\mathrm{SO}_{2}$ is strongly influenced by the suspension concentration on the entire studied temperature range, the absorption rate being greater at lower concentrations. This behavior of the absorbent system is determined by two categories of factors:

a) relating to the physical properties of the system, e.g. viscosity and $\mathrm{pH}$. The lower viscosity of diluted suspensions causes higher diffusion rates and therefore the increase of the absorption rate. At higher concentrations of suspension, the viscosity is higher, so that the rate of the diffusion process is lower. At the same time, at lower concentrations of suspension, the value of $\mathrm{pH}$ equal $5.0-5.5$ is quickly reached, and so the absorption process takes place;

b) relating to the mass transformation processes as chemical reaction, dissolution, formation and growth of germs. Reactions between $\mathrm{MeCO}_{3}$ and $\mathrm{H}_{2} \mathrm{SO}_{3}$ are carried out mainly in the outer surface of the granules, at $\mathrm{pH}=6.7-7$, when the $\mathrm{MeSO}_{3}$ is stable, with very low solubility in water. According to the proposed mechanism, $\mathrm{MeSO}_{3}$ reacts with $\mathrm{HSO}_{3}^{-}$resulting $\mathrm{Me}\left(\mathrm{HSO}_{3}\right)_{2}$, which is 50 to 100 times more soluble.

In diluted suspensions, the driving force of reaction products dissolution, $\Delta C=C^{s}-C^{v}$, is higher, the volume concentration $C^{v}$ being lower. In these conditions, crust is not formed at the surface of the granule, and the process can be described by the mechanism of granule with contractible core without crust.

The analysis of kinetic curves shows that the induction period depends on operation conditions, concentration and temperature. The induction period increases for the higher suspension concentrations and decreases with the increase of temperature. In the final stage of absorption it was observed a change in slope, suggesting a lower rate of the absorption, determined by the change of macro-kinetic mechanism, when the process is controlled by diffusion through the crust of the reaction products. The obtained results show that the most pronounced influence of suspension concentration on the absorption rate occurs at $293 \mathrm{~K}$. The influence of suspension concentration decreases with the increase of temperature. At $333 \mathrm{~K}$ the rate of absorption is the same for the suspension concentrations of $10 \%$ and $15 \%$, due to the increase of suspension viscosity and concentration of sulfites in the suspension, the driving force of the dissolution process decreases.

The temperature has a significant and complex influence on the rate of $\mathrm{SO}_{2}$ absorption into dolomite-brucite suspensions. The increase of the temperature leads to the decrease of suspension viscosity, thus increasing the rate of the diffusion processes. A more pronounced influence of temperature is manifested on mass transformation processes, as reaction, dissolution and germ growth, whose rate increases with temperature. The temperature influence on the absorption rate of $\mathrm{SO}_{2}$ into the dolomite-brucite suspensions is shown in Figure 2, for the $15 \%$ suspension. 
The analysis of the experimental data shows that for $5 \%$ concentration and temperature of $293 \mathrm{~K}$, the time required to obtain a conversion of $90 \%$ is $80 \mathrm{~min}$ and $110 \mathrm{~min}$ for the suspension concentration of $15 \%$. At the same time, for suspension concentrations of $5 \%$ and $10 \%$, the effect of temperature on the absorption process is small. At the suspension concentration of $15 \%$ the temperature has a significant influence, determined by the occurrence of the reaction products, when the determinant mechanism is the diffusion of the reactant through the crust.

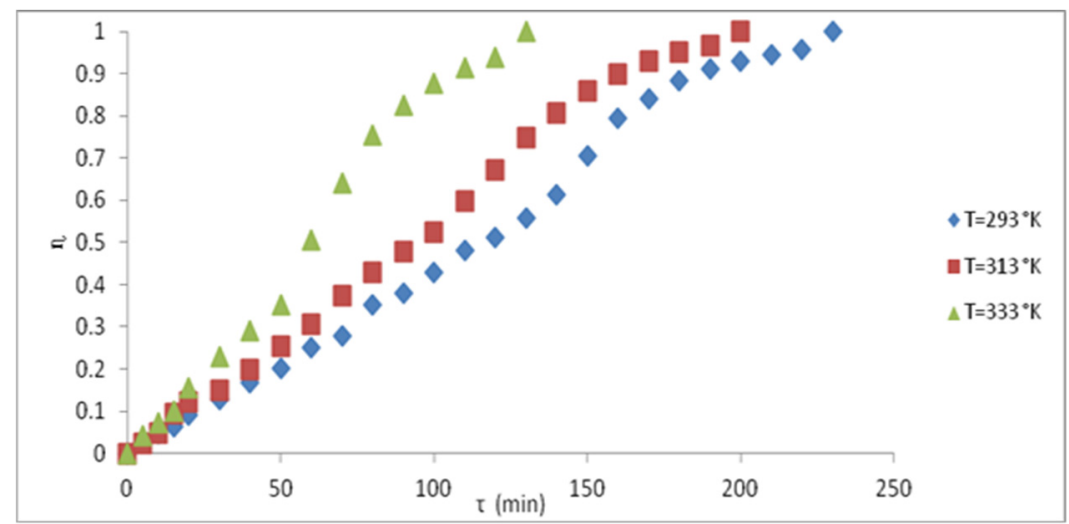

Figure 2. Temperature influence on $\mathrm{SO}_{2}$ absorption into dolomite-brucite suspension $15 \%$

Processing the data in coordinates $-\ln (1-\eta)$ versus time, specific diagrams as presented in Figures 3-5 are obtained. The analysis of diagrams shows the change of the slopes for investigated temperatures and suspension concentrations. This behavior suggests that the macro-kinetic mechanism of chemisorption process is modified.

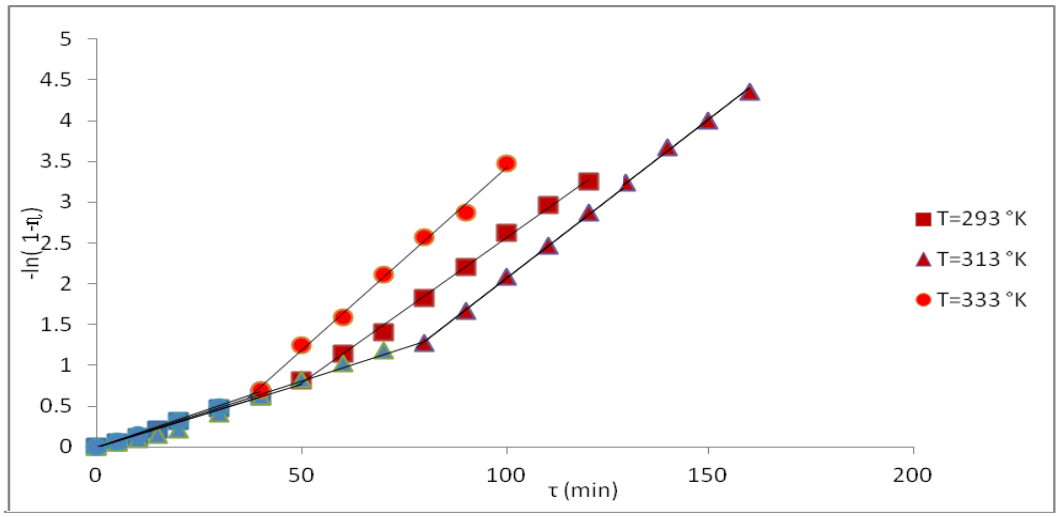

Figure 3. $-\ln (1-\eta)$ vs. time for $\mathrm{SO}_{2}$ absorption into the dolomite-brucite suspension $5 \%$ 


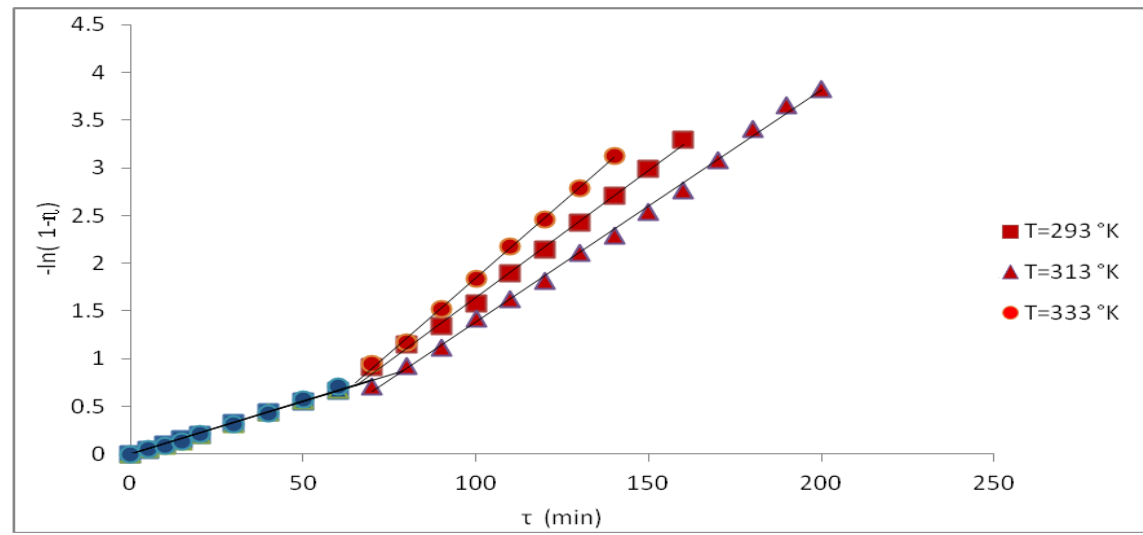

Figure 4. - In (1- $\eta)$ vs. time for $\mathrm{SO}_{2}$ absorption into the dolomite-brucite suspension $10 \%$

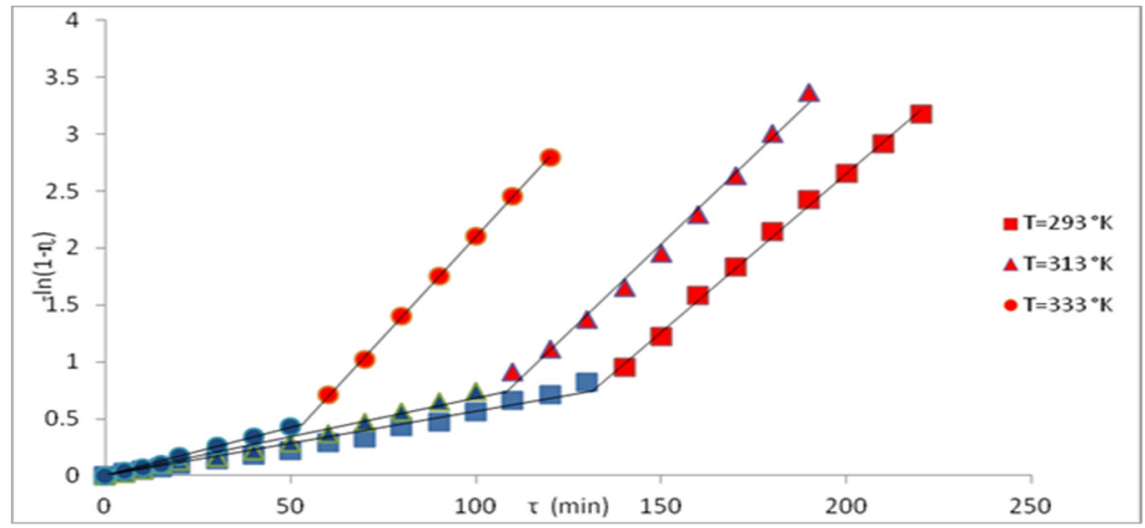

Figure 5. - In (1- $\eta)$ vs. time for $\mathrm{SO}_{2}$ absorption into the dolomite-brucite suspension $15 \%$

To determine the rate limiting step of the global process, the activation energies were calculated. The data are presented as Figure 6 shows for a concentration of $5 \%$.

The obtained results show, for each concentration and temperature, two values of the activation energy, $\mathrm{Ea}_{1}$ and $\mathrm{Ea}_{2}$ (Table1). The low values of activation energies, Ea $<25.1 \mathrm{~kJ} / \mathrm{mol}$, indicate for the working conditions that the absorption process takes place by diffusion. The transport processes as the mass transport of $\mathrm{SO}_{2}$ through the liquid phase at the beginning of the process, and the mass transport of $\mathrm{SO}_{2}$ through the crust of the reaction products at the end of the process, are limitative. 


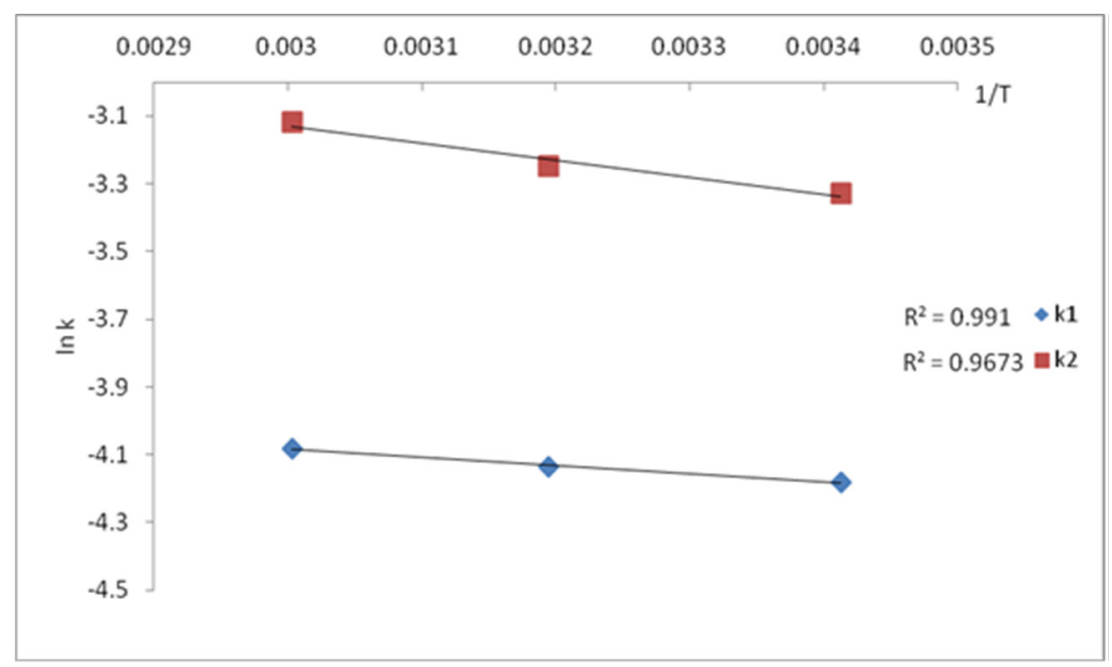

Figure 6. Diagram In k vs. 1/T for $\mathrm{SO}_{2}$ absorption into dolomite-brucite suspension $5 \%$

Table 1. The values of the activation energies

\begin{tabular}{|c|c|c|c|c|}
\hline Nr. crt. & $\begin{array}{c}\text { Suspension } \\
\text { conc. }\end{array}$ & Temp. & \multicolumn{2}{|c|}{ Activation energies } \\
\hline & $\mathbf{C}(\mathbf{w t} . \%)$ & $\mathbf{T}(\mathbf{K})$ & $\mathbf{E a}_{\mathbf{1}}$ (kJ/mol) & $\mathbf{E a}_{\mathbf{2}}$ (kJ/mol) \\
\hline 1 & 5 & $293-333$ & 2.001 & 4.17 \\
\hline 2 & 10 & $293-333$ & 4.55 & 8.37 \\
\hline 3 & 15 & $293-333$ & 0.544 & 5.11 \\
\hline
\end{tabular}

Comparing the values of the activation energies at the beginning period of the process, $\mathrm{Ea}_{1}$, with the corresponding values at the final period, $E a_{2}$, it was found for all concentrations that $\mathrm{Ea}_{1}<\mathrm{Ea}_{2}$. Thus, at low concentrations, the rate of the reaction products dissolution as $\mathrm{MgSO}_{3}$, $\mathrm{Mg}\left(\mathrm{HSO}_{3}\right)_{2}, \mathrm{Ca}\left(\mathrm{HSO}_{3}\right)_{2}$, is higher, the absorption takes place according to the model of grain without crust formation. In these conditions, the concentration of $\mathrm{HSO}_{3}^{-}$ions at the reaction surface (the outer surface of the granule) is sufficiently high so that the rate of chemical reactions $(4,7)$ is not the limitative stage in the process (see proposed mechanism).

The global rate is determined by the diffusion of $\mathrm{HSO}_{3}^{-}$ions through the liquid phase at the outer surface of the granule (external diffusion). $\mathrm{Ea}_{2}$ is twice higher than $\mathrm{Ea}_{1}$ for suspension concentrations of $5 \%$ and $10 \%$, and $\mathrm{Ea}_{2}$ is one time higher than $\mathrm{Ea}_{1}$ for the concentration of $15 \%$, probably due 350 
to the thickness of the reaction products crust. In the second period, corresponding to the final stage of absorption, the concentration of $\mathrm{Mg}\left(\mathrm{HSO}_{3}\right)_{2}$ and $\mathrm{Ca}\left(\mathrm{HSO}_{3}\right)_{2}$ in the liquid phase increases, the dissolution rate decreases, and the contribution of mass transformation processes increases. In these conditions, the activation energy $\mathrm{Ea}_{2}$ is higher than $\mathrm{Ea}_{1}$. At a dolomite-brucite concentration over $10 \%$, the concentration of solids in liquid phase increases too much, so that the reaction products as $\mathrm{Mg}\left(\mathrm{HSO}_{3}\right)_{2}$ and $\mathrm{Ca}\left(\mathrm{HSO}_{3}\right)_{2}$, are no longer dissolved. The reaction products remain as crust on the outer surface of the granule and the process takes place by the unreacted core model. Through the reaction products crust the access of $\mathrm{HSO}_{3}^{-}$ions to the reaction surface decreases, so that the rate of the chemical reaction decreases. Although the contribution of mass transformation processes increases, as emphasized by the higher $\mathrm{Ea}_{2}$ activation energy, the diffusion phenomenon through the crust (internal diffusion) remains limitative.

\section{Macro-kinetic mechanism of the process}

The wet process of $\mathrm{SO}_{2}$ absorption into calcium and magnesium carbonate suspension (slurry) is a complex process, with two basic stages: a) the mass transport (diffusion) through one of the phases (gas, liquid, solid); and b) the mass transformation as dissolution of reagents, chemical reaction, formation and growth of new phase germs.

Several mechanisms of $\mathrm{SO}_{2}$ absorption into the slurry of calcium carbonate are presented in the literature [16,21-26]. Figure 7 shows the structure of the global process proposed in the present study. According to this mechanism, the process is carried out in the liquid phase, after the calcium carbonate and sulfur dioxide dissolution. The analysis of the phase equilibrium shows that the solubility of the solid compounds participating in the reaction is very small (Table 2 ).

Table 2. Solubility data of the compounds $[27,28]$

\begin{tabular}{|c|c|c|c|c|c|}
\hline & \multicolumn{5}{|c|}{ Component } \\
\hline $\begin{array}{c}\text { Solubility } \\
\text { (g/100g sol.) }\end{array}$ & $\mathrm{CaCO}_{3}$ & $\mathrm{MgCO}_{3}$ & $\mathrm{Mg}(\mathrm{OH})_{2}$ & $\mathrm{CaSO}_{3}$ & $\mathrm{MgSO}_{3}$ \\
\cline { 2 - 6 } & 0.0069 & 0.2200 & 0.0084 & 0.0054 & 0.5250 \\
\hline
\end{tabular}

The low solubility of the carbonates (Table 2) correlated with the low dissolution rates, excludes the possibility of full reaction between $\mathrm{SO}_{2}$ and carbonates in the liquid phase. 


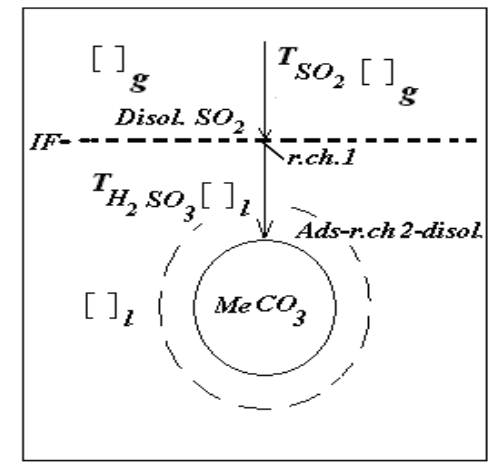

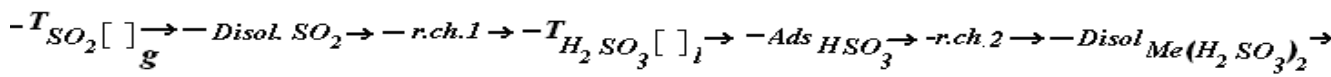

Figure 7. The sequence of elementary stages in the global process

Based on the macro-structural element of the mass reaction, the characteristic equation can be written as:

$$
\begin{aligned}
& {\left[\mathrm{CaCO}_{3}+\mathrm{MgCO}_{3}+\mathrm{Mg}(\mathrm{OH})_{2}+\mathrm{A}^{\prime \prime}\right]_{s}+\left[\mathrm{H}_{2} \mathrm{SO}_{3}+\mathrm{SO}_{2}+\mathrm{H}_{2} \mathrm{O}\right]_{l} \rightarrow} \\
& {\left[\mathrm{CaCO}_{3}+\mathrm{MgCO}_{3}+\mathrm{Mg}(\mathrm{OH})_{2}+\mathrm{CaSO}_{3}+\mathrm{MgSO}_{3}+\mathrm{A}^{\prime \prime}\right]_{s}+} \\
& {\left[\mathrm{Ca}\left(\mathrm{HSO}_{3}\right)_{2}+\mathrm{Mg}\left(\mathrm{HSO}_{3}\right)_{2}+\mathrm{H}_{2} \mathrm{SO}_{3}+\mathrm{H}_{2} \mathrm{O}\right]_{l}+\left[\mathrm{CO}_{2}\right]_{g}}
\end{aligned}
$$

The mass transformation processes, in accordance with the characteristic equation, are:

$$
\begin{aligned}
& \mathrm{SO}_{2[]_{g}} \rightleftarrows \mathrm{SO}_{2 a q} \\
& \mathrm{SO}_{2 a q}+\mathrm{H}_{2} \mathrm{O} \rightleftarrows \mathrm{H}_{2} \mathrm{SO}_{3 a q} \\
& \mathrm{H}_{2} \mathrm{SO}_{3 a q} \rightleftarrows \mathrm{H}^{+}+\mathrm{HSO}_{3 a q}^{-} \\
& \mathrm{MeCO}_{3]_{s}}+\mathrm{HSO}_{3 a q}^{-} \longrightarrow \mathrm{MeCO}_{3} * \mathrm{HSO}_{3 a d s}^{-} \\
& \mathrm{MeCO}_{3} * \mathrm{HSO}_{3 a d s}^{-} \longrightarrow \mathrm{MeSO}_{3]_{s}}+\mathrm{HCO}_{3 a q}^{-} \\
& \mathrm{SO}_{2 a q}+\mathrm{H}_{2} \mathrm{O}+\mathrm{HCO}_{3}^{-} \longrightarrow \mathrm{HSO}_{3}^{-}+\mathrm{CO}_{2}+\mathrm{H}_{2} \mathrm{O} \\
& \mathrm{MeSO}_{3[] s}+\mathrm{HSO}_{3}^{-}+\mathrm{H}_{2} \mathrm{O} \longrightarrow \mathrm{Me}_{2}\left(\mathrm{HSO}_{3}\right)_{2[] s}+\mathrm{H}^{+} \\
& \mathrm{Me}\left(\mathrm{HSO}_{3}\right)_{2[]_{s}} \longrightarrow \mathrm{Me}\left(\mathrm{HSO}_{3}\right)_{2 a q} \\
& \mathrm{H}^{+}+\mathrm{HCO}_{3}^{-} \longrightarrow \mathrm{H}_{2} \mathrm{O}+\mathrm{CO}_{2}
\end{aligned}
$$


In the absorption zone, in addition to reactions (1)-(9), secondary reactions (10)-(11) and the oxidation of the sulfites can take place (12)-(13):

$$
\begin{aligned}
& \mathrm{Ca}\left(\mathrm{HSO}_{3}\right)_{2}+\mathrm{O}_{2} \longrightarrow \mathrm{CaSO}_{4 a q}+\mathrm{H}_{2} \mathrm{SO}_{4} \\
& \mathrm{CaSO}_{4 a q}+2 \mathrm{H}_{2} \mathrm{O} \longrightarrow \mathrm{CaSO}_{4} \cdot 2 \mathrm{H}_{2} \mathrm{O}_{[] s} \\
& \mathrm{Mg}\left(\mathrm{HSO}_{3}\right)_{2}+\mathrm{O}_{2} \longrightarrow \mathrm{MgSO}_{4 a q}+\mathrm{H}_{2} \mathrm{SO}_{4} \\
& \mathrm{MgSO}_{4 a q}+2 \mathrm{H}_{2} \mathrm{O}+\mathrm{Ca}\left(\mathrm{HSO}_{3}\right)_{2} \longrightarrow \mathrm{CaSO}_{4} \cdot 2 \mathrm{H}_{2} \mathrm{O}_{[] s}+\mathrm{Mg}\left(\mathrm{HSO}_{3}\right)_{2}
\end{aligned}
$$

The structure of the process can be now illustrated by the diagram shown in Figure 8.

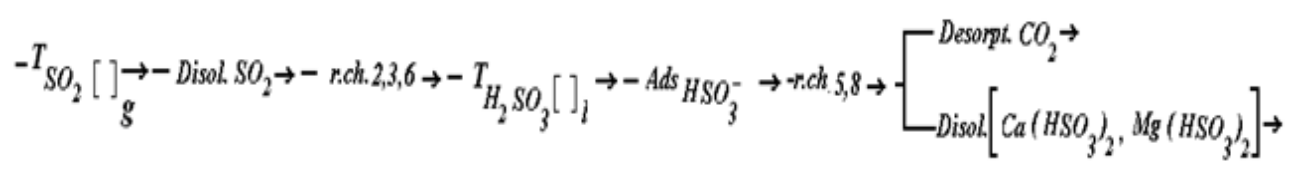

Figure 8. Process structure of the gas desulphurization with dolomite-brucite suspension

According to the process structure above, the reaction between dolomite-brucite particles and sulfurous acid has shown three possible macro-kinetic mechanisms: a) the transport of the reactants into fluid phase; b) the mass transformation processes as chemical reactions in the liquid phase or at the surface of dolomite-brucite particles; and c) the combined model as mass transport into the fluid phase-transformation.

\section{CONCLUSIONS}

Based on the study of the sulfur dioxide chemisorption into wet dolomite-brucite suspension, a new macro-kinetic mechanism was proposed according to which the chemical reaction between $\mathrm{H}_{2} \mathrm{SO}_{3}$ and $\mathrm{MeCO}_{3}$ takes place into the adsorbed layer, at the outer surface of the granules. The influence of the concentration of the dolomite-brucite suspension and of the temperature on the global process was determined.

The process analysis by the activation energies suggests that $\mathrm{SO}_{2}$ chemisorption in dolomite-brucite suspensions takes place after the macrokinetic model in which the diffusion is the limitative step. At suspension concentrations lower than $5 \%$ and high temperatures, the chemisorption process takes place according to the shrinking core model, without crust, 
when the diffusion of $\mathrm{H}_{2} \mathrm{SO}_{3}$ through the liquid phase is the limitative stage. At concentrations higher than $10 \%$ the chemisorption process is carried out according to the unreacted core model with crust formation of reaction products, when the diffusion through the crust of products remains the limitative phenomenon.

\section{EXPERIMENTAL SECTION}

The sulfur dioxide absorption was carried out in a laboratory cylindrical batch reactor, as was described in [29]. The evolution of the process was determined by weighing the samples collected with a pipette from the absorption reactor, at each 5 minutes. After weighing, the samples were diluted with about $100-150 \mathrm{~mL}$ distilled water. The $\mathrm{SO}_{2}$ dosing was carried out using iodometric means, with $0.05 \mathrm{~N}$ iodine solution in the presence of starch.

The dolomite-brucite suspensions used in the research had three concentrations: $5 \%, 10 \%$ and $15 \%$. Working temperatures were $293 \mathrm{~K}, 313$ $\mathrm{K}$ and $333 \mathrm{~K}$. The absorbent suspension was prepared using dolomitebrucite solid obtained by grading on Retzsch sieves, with the size less than $125 \mu \mathrm{m}$. The analysis with Coulter-Counter device indicates a mean particle size $d_{50 \%}$ of $2.75 \mu \mathrm{m}$.

Due to the fact that the rate of desulphurization process depends on the reactivity of the suspension, the main textural properties and chemical composition of dolomite-brucite have been determined. Textural properties were investigated with surface area analyzer Qsurf Series M1. The specific surface area of the samples was determined by measuring nitrogen adsorption/desorption isotherms at $77 \mathrm{~K}$, using the Brunauer, Emmett and Teller $(B E T)$ relation. The specific surface $\left(\mathrm{S}_{\text {spec. }}\right)$ area as the average of three measurements was found to be $1.5 \mathrm{~m}^{2} / \mathrm{g}$.

Table 3. The composition, specific surface area and porosity of the dolomite-brucite rock

\begin{tabular}{|c|c|c|c|c|c|}
\hline Component & $\mathrm{CaCO}_{3}$ & $\mathrm{Mg}(\mathrm{OH})_{2}$ & $\mathrm{MgCO}_{3}$ & $\mathrm{SiO}_{2}$ & $\mathrm{H}_{2} \mathrm{O}$ \\
\hline (wt.\%) & 62.98 & 21.35 & 2.34 & 3.23 & 10.03 \\
\hline$S_{\text {spec. }}\left(m^{2} / g\right)$ & \multicolumn{5}{|c|}{1.5} \\
\hline Porosity $\left(\mathrm{cm}^{3} / \mathrm{g}\right)$ & & & 0.0052 & & \\
\hline
\end{tabular}

TG analysis indicates that dolomite-brucite contains three principal compounds, $\mathrm{CaCO}_{3}, \mathrm{MgCO}_{3}$ and $\mathrm{Mg}(\mathrm{OH})_{2}$, with a very compact form at the room temperature, which is confirmed by the very low values of the specific surface area and porosity. 
KINETIC STUDY OF SULFUR DIOXIDE ABSORPTION INTO DOLOMITE-BRUCITE SUSPENSIONS

\section{REFERENCES}

1. J. B. W. Frandsen; S. Kiil; J. E. Johansson; Chem. Eng. Sci., 2001, 56, 32753287

2. Y. S. Kang, S. K. Sung. S.C. Hong; J. Ind. Eng. Chem., 2015, 30, 197-203

3. F. J. Gutierrez Ortiz; F. P. Vidal; L. S. Ollero; V. Cortes; Ind. Eng. Chem. Res., 2006, 45, 1466-1477

4. I. Hrastel; M. Gerbec; A. Stergaršek; Chem. Eng. \& Technol.; 2007, 30, 220-233

5. Y. Wu; Q.Li; F. Li; Chem. Eng. Sci., 2007, 62, 1814-1824

6. X. Li; C. Zhu; Y. Ma; Front. Chem. Sci. Eng., 2013, 7, 185-191

7. G. Muthuraman; Moon II-Shik; J. Ind. Eng. Chem, 2012, 18, 1540-1550

8. T. Hlincik; P. Buryan; Fuel Process. Technol.; 2013, 111, 62-67

9. T. Hlincik; P. Buryan; Fuel; 2013, 104, 208-215

10. R. Valle-Zermeño; J. Formosa; J. M. Chimenos; Rev. Chem. Eng., 2015, 31, 303-310

11. S. C. Stultz; J. B. Kitto; Steam: its generation and use, Ed. Babcock \& Wilcox, Barberton, Ohio, 2005, Chapter 1, pp. 1-17

12. S. Shafiee; E. Topal; Energy Policy, 2008, 36, 775-786

13. A. Kohl; R. Nielsen; Gas purification, $5^{\text {th }}$ Edition, Gulf Publishing Company, Elsevier, Houston, Texas, 1997, Chapter 1, pp. 466-670

14. N. Karatepe; Energy Sources; 2000, 22, 197-206

15. A. Gómez; N. Fueyo; A. Tomás; Comput. Chem. Eng. 2007, 31, 1419-1431

16. C. Brogren; H. T. Karlsson, Chem. Eng. Sci, 1997, 52, 3085-3099

17. Y. Zhong; X. Gao; W. Huo; Z. Y. Luo; M. J. Ni; K. F. Cen; Fuel Process. Technol., 2008, 89, 1025-1032

18. B. Dou; W. Pan; Q. Jin; W. Li; Y. Wang; Energy Conv. Manage, 2009, 50, 25472553

19. P. Taerakul; P. Sun; D. W. Golightly; H. W. Walker; L. K. Weavers; B. Zand; T. Butalia; T. J. Thomas; H. Gupta; L. S. Fan; Fuel, 2007, 86, 541-553

20. L. E.Kallinikos; E. I. Farsari; D. N. Spartinos; N. G. Papayannakos; Fuel Process. Technol., 2010, 91, 1794-1802

21. P. A. Ramachandran; M. M. Sharma; Chem. Eng. Sci.,1969, 24, 1681-1686

22. C. Brogren; H. T. Karlsson; Ind. Eng. Chem. Res., 1997, 36, 3889-3897

23. S. Y. Liu; W. D. Xiao, Chem. Eng. Technol., 2006, 29, 1167-1173

24. B. Dou; Y. C. Byun; J. Hwang; Energy \& Fuel, 2008, 22(2), 1041-1045

25. S. Kiil; M. L. Michelsen; K. Dam-Johansen; Ind. Eng. Chem. Res., 1998, 37, 2792-2806

26. S. Dragan; A. Ozunu; Central Eur. J. Chem., 2012, 10, 1556-1564

27. R. H. Perry; Perry's Chemical Engineering Handbook, Section 2, Physical and Chemical Data, $8^{\text {th }}$ Edition, McGraw Hill., 2008, Chapter 2, pp. 121-124

28. M. R. Masson; H. D. Lutz; B. Engelen; Solubility Data Series, Sulfites, Selenites and Tellurites, Pergamon Press, Oxford, 1986, Chapter 26, pp.153-220

29. S. Dragan; Studia UBB Chemia, 2017, 62(4), 283-291 